\title{
BESIFORMUOJANČIO VILNIAUS MODERNIOJO CENTRO URBANISTINIS MODELIS
}

\author{
Saulius Motieka \\ St „Vilniaus planas“, Konstitucijos pr. 3, LT-09601 Vilnius, Lietuva \\ Urbanistikos katedra, Vilniaus Gedimino technikos universitetas, \\ Pylimo g. 26/Traku g. 1, LT-01332 Vilnius, Lietuva \\ El.paštassaulius.motieka@vplanas.lt
}

Iteikta 20090724

Santrauka. Vilniaus identiteto tęstinumui bei tolimesniam kokybiško sostinès įvaizdžio formavimui didelę svarbą turi šiuo metu stichiškai besivystančio Neries dešiniojo kranto ir „,architektūrinès kalvos“ tolimesnės raidos urbanistiniai principai. Nereguliuojamos plètros toleravimas darytų didžiausią neigiamą poveikị miesto identitetui, kraštovaizdžiui, kultūros paveldui, materialiam turtui ir šių veiksnių tarpusavio sąveikai. Todèl būtina nusistatyti aiškius metodinius moderniojo centro plètros principus, kurie apibrěžtų vientisą urbanistinį centro ịvaizdị, užtikrintų planuojamos teritorijos polifunkciškumą visuomeninių interesų atžvilgiu. Taptų aiškios investicinès erdvès galimybès, reglamentuotos sąlygos kultūriniam ir gamtiniam savitumui saugoti, ryškinti ir racionaliai naudoti, atsirastų objektyvios galimybès planuojamos teritorijos plètrai valdyti ir svarbiausiems reglamentams nustatyti.

Reikšminiai žodžiai: užstatymo morfotipas, urbanistinè struktūra, viešoji erdvė, užstatymo daugiaplaniškumas, „architektūrinė kalva“.

\section{Ivadas}

$2008 \mathrm{~m}$. pabaigoje buvo pradèta rengti naujojo centro dešiniajame Neries krante urbanistinių parametrų studija, kuria remdamasi savivaldybé galètų nustatyti sąlygas ir planuojamų teritorijų apimtị kito lygmens nei miesto bendrasis planas teritorijų planavimo dokumentams rengti.

Nagrinėjamos teritorijos plotas apėmè gana didelị besiformuojančio moderniojo sostinès centro segmentą nuo kairiojo Neries kranto Goštauto gatvès užstatymo pietuose iki Krokuvos gatvės šiaurèje ir nuo Kalvarijų gatvès perimetro rytuose iki Neries upès senvagès vakaruose.

$2009 \mathrm{~m}$. viduryje parengta urbanistinių parametrų studija buvo pristatyta Lietuvos architektų sąjungos Vilniaus miesto architektūros ir urbanistikos ekspertų tarybai ir susilaukè nevienareikšmių diskusijų ir vertinimų, kurių rezultatas buvo daugiau grožio (estetinių) kategorijų aptarimas, o ne pateiktų problemos sprendimo principų analizè.
Šio straipsnio tikslas pristatyti per tyrimą suformuluotus metodologinius pagrindus planuojamos urbanistinès situacijos struktūrai identifikuoti ir užstatymo reglamentavimo principams nustatyti.

Kol straipsnis buvo rengiamas spaudai, Vilniaus miesto savivaldybès taryba dalyje planuojamos teritorijos aprobavo pagal straipsnyje pristatomą metodiką parengtus projektinius siūlomo urbanistinio modelio parametrus.

\section{Problema ir uždaviniai}

Nuo nepriklausomybès paskelbimo praėjo nemažai laiko, o valstybingumo urbanistinio ịprasminimo, deja, neturime. Visi didieji miestai tokiems įvykiams jamžinti sutelkia jègas ir palieka ateities kartoms tam tikrą materialų paveldą - t. y. žymes urbanistiniame audinyje, ilgainiui igaunančias semantines prasmes. 
Daug kalbama apie naujojo miesto centro kūrimą dešiniajame Neries krante. Konstitucijos prospektas ir jo aplinka Šnipiškèse dažnai tapatinami su postsovietinès materialios kultūros simboline išraiška. Tačiau kol kas tai yra tik vienas iš problematiškiausių sostinès statybos poligonų, kuriame eksperimentuojama, bet, kuris dar neturi aiškaus apibrèžtumo ir integralios urbanistinės architektūrinès darnos esamų ir konvertuojamų teritorijų aplinkoje. Literatūrinè moderniojo centro idejos samprata niekada nebuvo susieta su urbanistiniais veiksniais, nebuvo ivertinta ir formuojama profesionaliomis kategorijomis, todèl iki šiol ir neturi vientisos urbanistinès kompozicijos požymių. Atėjo laikas pripažinti, kad toks neapibrèžtumas ateityje gali turèti lemiamų neigiamų ir nepataisomų pasekmių Vilniaus identiteto tęstinumui bei tolimesniam kokybiško sostinès įvaizdžio formavimui. Kalbama ne apie atskirus pastatus ar jų estetinę išraišką, o apie platesnès prasmès kategoriją - vietovés urbanistinio komplekso modeli (toliau - nagrinejjama teritorija). Kitaip sakant, kalbama apie taisykles, kurių laikantis dar ịmanoma sustabdyti ịsibègèjantị architektūrinès anarchijos procesą ir palaipsniui baigti formuoti polifunkcinio, prasmingo, priimtinos kondicijos ir konsistencijos svarbiausios miesto dalies naujo kompozicinio vieneto viziją, atitinkančią šiuolaikines industrines ir kultūrologines doktrinas.

Darnus, tvarus miestas ateities kartoms turi palikti geresnę miesto aplinką. Daugelis mūsų nesilaiko šio požiūrio, nes didina vartojimą, paiso tik asmeninių poreikių ir dèl to artejja prie kritinès aplinkos išnaudojimo ribos. Mums reikia gyvybingų miestų, kur būtų ribojamas piktnaudžiavimas aplinka, stengiamasi išvengti socialinès izoliacijos (Rodgers, Power 2004).

Siekiant pagerinti ịvaizdị, aplinkos kokybę ir užtikrinti išskirtinumą, reikalingos sisteminès, koncentruotos pastangos formuojant vientisus kompaktiškus miesto morfologinius vienetus, organizuojant funkciškai ir socialiai integruotą teritorijos struktūrą. Išskirtinè urbanistinè morfologija apibūdina miestą, atitinkamai atriboja ji nuo kaimo ir lemia jo identitetą. Kol kas dabartinio urbanistinio kompleksiškumo samprata apsiriboja projektuojamų pastatų vertinamu vizualinių pasekmių aspektu iš vadinamų „reikšmingų senamiesčio apžvalgos taškų“. Toks vertinimas nèra pakankamai argumentuotas ir reikšmingas vertinant struktūrines pasekmes. Pavyzdžiui, žiūrint iš Subačiaus apatinės terasos apžvalgos aikštelės, besiformuojanti „architektūrinè kalva“, prasidedanti vakarinèje dalyje, yra mandagiai atsitraukusi nuo Gedimino kalno.
O žvelgiant nuo Subačiaus aukštutinès terasos - naujasis užstatymas tarsi karūna užsirioglina ant Gedimino pilies bokšto. Taip jau yra su tuo vizualinių pasekmių vertinimo patikimumu. Aišku, šis aspektas yra taip pat labai svarbus, bet jis naudotinas tik struktūrinei darnai, jos galimoms pasekmèms identifikuoti, o ne atskiriems pastatams integruoti grožiui demonstruoti esamo užstatymo kontekste.

Vilniaus miesto bendrasis planas iki 2015 metų nagrinëjamą teritoriją numato kaip išskirtinę miesto centro funkcinę zoną, kurios visi teritoriniai parametrai nustatomi ir tikslinami rengiant kito lygmens teritoriju planavimo dokumentus.

Parengti ir šiuo metu galiojantys detalieji planai yra sukurti tam, kad visą teritoriją būtų galima pasiskirstyti įtakos zonomis. Investicinių vizijų ir bandymų realizuoti „teisètus lūkesčius“ siūlymuose dažniausiai neatsižvelgiama ị struktūrinius teritorijos užstatymo principus ir nenagrinejamos galimos lokalizuoto planavimo kontekstualios pasekmès. Tokiuose teritoriju planavimo dokumentuose reglamentuojama ne urbanistinè architektūrinė kokybè, o tik užtikrinama maksimali esamos nuosavybès galimos realizacijos apimtis, tenkinanti privačius interesus.

Šiuo metu galioja ir Šnipiškių rajono plètojimo raidos programa. Joje nurodyti užstatymo morfologijos ir aukštingumo principai, t. y. pagrindiniai nagrinèjamos teritorijos konversijos dydžiai ir jų realizavimo taisyklès. Tačiau vèl gi, projektuojant tik atskirus lokalius objektus (jų integralumas bendrame kontekste ne tik urbanistiniu, bet ir socialiniu požiūriu šiuo metu niekam neįdomus), ir toliau naudojamas tas pats scenarijus - imant galimus maksimalius užstatymo rodiklius, per jęgą bandoma savaip, dažniausiai lokaliai juos interpretuoti, dèl to atsiranda toliau pateikiamos neigiamos, o kartais ir nebepataisomos pasekmès, kai nèra apsispręsta dèl baigtinès urbanistinès kokybès parametrų:

- deformuojami nustatyti vertikalūs parametrai ir užstatymo tankumas beveik visame planuojamo naujojo miesto centro plote;

- niveliuojant teritorijos hierarchinius principus funkciniu požiūriu, urbanizuojamos visos laisvos teritorijos, nepaliekant galimybių lokalių viešųjų mikroerdvių sistemai sukurti;

- Konstitucijos prospekto pietinè išklotinè formuojama nesilaikant urbanistinès logikos - stambinami tūriai ir didinamas užstatymo aukštingumas;

- nepagrịstai ir beatodairiškai aukštinamas užstatymas rytų kryptimi, stambūs architektūriniai tūriai perkeliami ị kitą Kalvarijų gatvės pusę. 
Tolimesnis nereguliuojamos plètros toleravimas plačiąja prasme padarys didžiausią neigiamą poveikị miesto įvaizdžiui, gamtinei aplinkai, kultūros paveldui ir visuomeniniam požiūriui. Tai yra tiesiogiai susiję su kuriamos urbanistinès architektūrinès kokybès parametrais ir Vilniaus urbanistinio identiteto principais. Ieškant šių kriterijų sąsajų ir siekiant pagrịsti urbanistinị integruotumą, užstatymo aukštingumą ir intensyvumą, galiausiai atrandamos tinkamiausios priemonès, kurias taikant galima sèkmingai tobulinti naujojo centro erdvinę struktūrą, ansambliškumą ir vystyti bendrąją urbanistinę sistemą.

\section{Istorinès raidos apžvalga}

Analizuojamos teritorijos istorinei urbanistinei raidai didelę įtaką turèjo Neries upè ir gamtinè aplinka. Greta stovejęs vienintelis tiltas per upę lèmè urbanistinès struktūros pamatą. Šnipiškių priemiestį formavo dvi pagrindinès nuo Žaliojo tilto prasidedančios gatvès, kurių viena vedè $\mathfrak{i}$ Ukmergę, o kita $\mathfrak{i}$ Verkius (Drèma 1991). Didelę teritorijos dalį užèmè užliejamos pievos.
Miesto plètrai šiaurès kryptimi perspektyviniuose 1875 m. ir 1904 m. miesto vystymo planuose Šnipiškèse buvo suprojektuotas naujas reguliarus gatvių tinklas (1 pav.), kuriuo remiantis turèjo būti suintensyvintas ir sumodernintas dešiniojo upès kranto užstatymas. Tačiau iki Antrojo pasaulinio karo realizuota tik šiaurinè dalis.

Pagrindinis urbanistinis akcentas iki 20 a. paskutinio ketvirčio buvo Šv. Rapolo bažnyčia. Teritorija iki pat upès visais laikais daugiau ar mažiau buvo urbanizuota. Šalia padriko gyvenamojo užstatymo atsiradę gamybiniai pastatai ir įrenginiai vietovei suteikè individualių urbanistinių bruožų lyginant su kitais priemiesčiais. Užstatymas savo vizualiniais ryšiais integravosi i dešinijji krantą. Todèl nèra logiški dabartiniai tvirtinimai, kad šiuo metu dešinèje upès krantinèje yra natūrali ir unikali gamtinè aplinka. Dabar viso labo čia yra pievos, atsiradusios sunaikinus buvuși istorinị užstatymą.

XX a. kairiajame Neries krante ties Lukiškèmis pradejjus formuoti naują miesto centrą, abiejų upés krantų vizualinių ryšių struktūros integralumas dar labiau

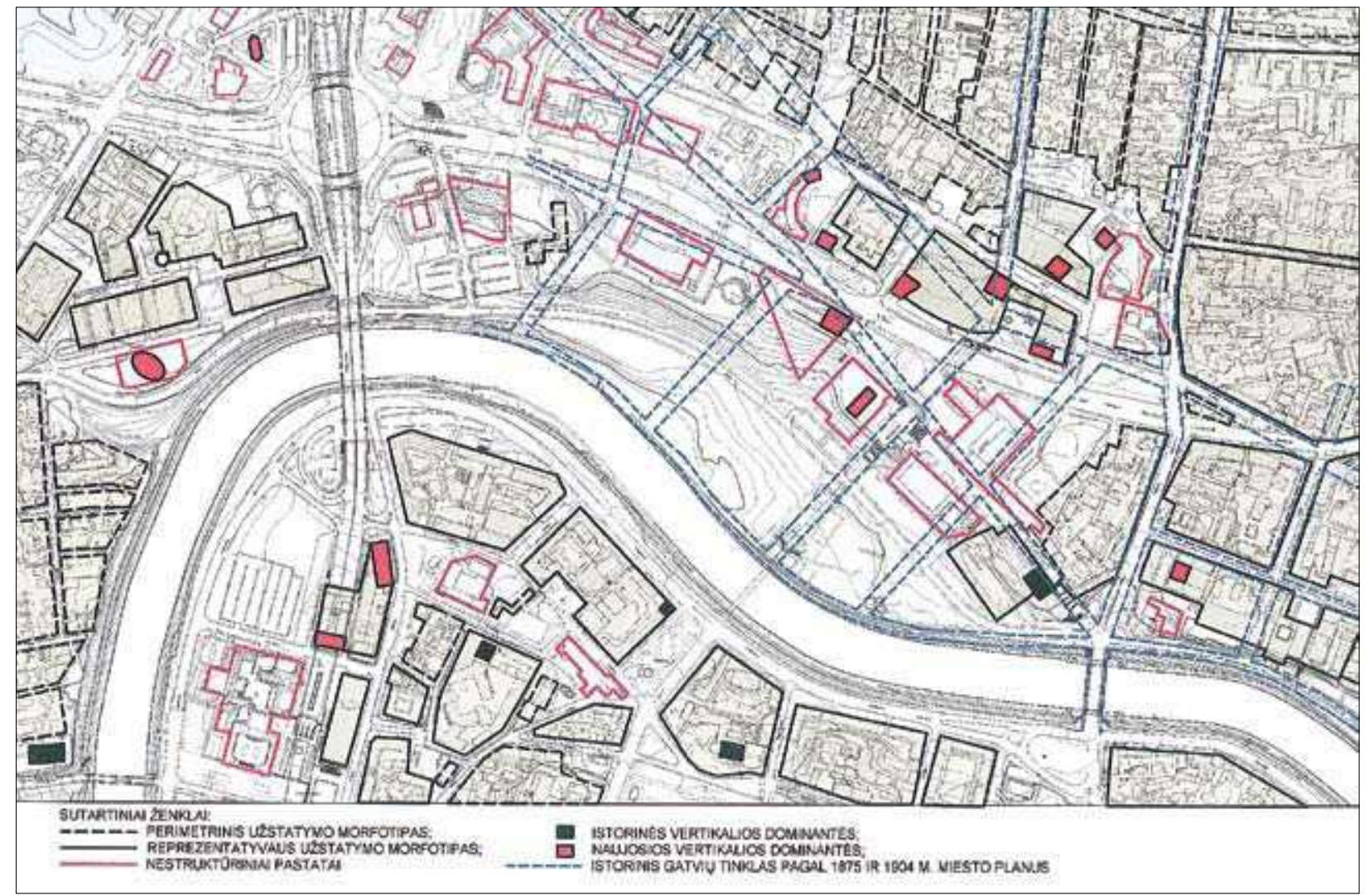

1 pav. Esamas užstatymas 2009 m. ir orientacinis gatvių tinklas pagal $1904 \mathrm{~m}$. Vilniaus miesto planą

Fig. 1. Existing built-up areas in 2009 with approximate street network in Vilnius City Plan of 1904 
išryškejjo. Naujo tilto (dabartinio Baltojo tilto ašyje) jungtis turèjo sudaryti struktūrines prielaidas dešiniojo Neries kranto urbanistiniam karkasui formuoti. Upès senvagè ir tuometinio miesto vyriausiojo architekto V. Mikučianio rūpesčiu apželdinti pliki Šeškinès kalvų šlaitai kaip kompozicinè atsvara miškingoms Antakalnio kalvoms (Mikučianis 2001) pretendavo i dar vieną struktūriškai svarbią žaliojo karkaso jungtị. Dabartiniu metu šie jau suaugę medynai suformavo miestui unikalų žaliąji foną šiauriniame horizonte, bet planuotos struktūrinès gamtinio karkaso jungties požymiai beveik išnyko.

„Po Antrojo pasaulinio karo prasidèjęs spartus urbanizacijos procesas, sunaikinęs buvusią valdų struktūrą ir pirmykštị reljefą, radikaliai pakeitè buvusią teritoriją. Iš atsilikusio priemiesčio per pusę amžiaus teritorija transformavosi ị iš esmès naują urbanistinę ir architektūrinę išraišką" (Racevičienè, Baliulytè 2008). Istoriniai keliai ir struktūrinès gatvès buvo visiškai sunaikintos ir sukurtos naujos komunikacinès trasos. Išliko tik senasis istorinis ryšys Žaliojo tilto ašyje. Naujas komunikacinis koridorius - Geležinio Vilko tiltas per Nerị su išvystytais transporto mazgais (užmiesčio kelių elementais) - galutinai pakeite dešiniojo kranto teritorijos ịvaizdị ir pobūdị.

„Sparčiai pažengus urbanizacijos procesui, urbanistinè vietovès tradicija neteko prasmès ir negali būti vertinama kaip vertingoji savybè. Sunaikinus istorinị gatvių tinklą, posesijinę struktūrą bei užstatymą, nagrinëjamos vietovès vertingąja savybe galima būtų laikyti jos vizualinius ryšius su upe, kairiojo jos kranto urbanistiniu audiniu bei istoriniu miesto centru - senamiesčiu. Tolimesnę teritorijos plètrą turètų diktuoti bendri miesto vystimosi procesai ir darni visuma su gamtine ir vizualine apsuptimi, išlaikant istoriškai susiformavusią šiaurès-pietų vizualinę ir fizinę ašị “ (Racevičiené, Baliulytė 2008).

Planuojama teritorija turejo skirtingą svarbą ir ivaizdį miesto istorinès raidos kontekste. Išsiskyrè labai aiškios kaminų vertikalès, išdèstytos šalia vizualinių kanalų, o ne, kaip dabar labai madinga, kanalų ašyse tai unikalus Vilniaus vertikalių akcentų statymo pavyzdys. Šis konceptualus principas ir toliau turètų būti taikomas kuriant naujas urbanistines struktūras.

Dalis vertingo vietovès architektūrinio archetipo išliko ir iki šių dienų. Jị ir toliau vertètų saugoti kaip unikalų miesto savitumo bruožą dešiniajame Neries krante. Vietovès urbanistinio karkaso orientacija, mastelis ir besikeičiantis intensyvumas, kvartalų dydžiai yra svarbūs motyvai, užtikrinantys dešiniojo ir kairiojo
Neries krantų struktūrinį vientisumą ir šios sandaros apsaugą semantiniu aspektu.

Transformavus Ukmergès trakto trajektoriją, teritorinis segmentas tarp Žaliojo ir Geležinio Vilko tiltų formavosi stichiškai, išsižadant aiškios ir nuoseklios kompozicinès sistemos ir realizuojant pavienius ambicingus objektus. Todèl ši teritorija ir šiandien yra viena iš chaotiškiausių miesto erdvių vertinant ne tik urbanistiniu, bet ir viešųjų erdvių harmonizavimo požiūriu, nes pritaikyti žalių viešųjų erdvių sąvoką pievoms ir neturintiems urbanistinio bei funkcinio ịprasminimo želdiniams yra niekas kitas, kaip tik neatsakingas tuščiažodžiavimas.

Kita nuolatinių diskusijų tema - aukštybinių pastatų atsiradimas ir jų traktavimas naujojo centro kontekste. Dar 2003 m. prof. A. Vyšniūnas prognozavo bręstantį konfliktą. „Didelè problema - norimų rezultatų, kaip moksliškai patikrintų duomenų apie galimas pasekmes, kokybiškas apibūdinimas. Norimo rezultato aiškios definicijos (formaliai sutartos ar moksliškos) nebuvimas iš anksto užprogramuoja galutinio rezultato individualias traktuotes ir interpretacijas. Neaišku, kas ir pagal kokius kriterijus gali objektyviai ịvertinti galutini rezultata tuo atveju, kai nèra susitarta dèl kokybiško rezultato požymių"(Vyšniūnas 2003).

Tobulinant naujojo centro urbanistinę struktūrą, būtina atsižvelgti ị daug platesnị teritorinị kontekstą. Tai yra tam tikras susiformavęs aplinkos standartas, lemiantis teritorijos identiteto pagrindus ir turintis daugybę funkcijų, sudarančiu prielaidas harmoningai teritorijos raidai (Лебедев 1975). Tik taip galima nustatyti ir įrodyti metodiškai pagrịstą teritorijos užstatymo morfotipą, fonini aukštingumą, identifikuoti vietas, kur gali atsirasti vertikalios dominantės, ir aprašyti jų fizinius parametrus.

\section{Esamos būklès urbanistinis vertinimas ir planavimo principu prielaidos}

Teritorijos urbanistinis vertinimas yra pagrịstas kompleksine teritorijos analize, nes planinè erdvinè struktūra yra neatsiejama nuo užstatymo pobūdžio, unikalumo topografinèje aplinkoje, socialinio bei funkcinio îprasminimo. Esant išskirtiniam žemès paviršiaus terasuotumui, galima teigti, kad prognozuojamo užstatymo pobūdis turètų prisitaikyti prie šio unikalaus gamtinio veiksnio. Neries slènio erdvès pereina į daugiaplanes panoramas. Šlaitų reljefo skirtumo intensyvumas lemia slénio vizualinio baseino ribų pobūdị - daugiaplaniškumą, panoramų gausą, 
skirtingus vizualinio suvokimo lygius, užsibaigiančius žaliųjų šlaitų siluetais (Daujotaitė, Malžinskienẻ 2003).

\section{Besiformuojančio komplekso planinès struktūros analizè}

Planiné struktūra vertinama remiantis užstatymo morfotipo priklausomybe nuo ekonominių veiksnių, lemiančių elementarųji užstatymo modulị. Šis principas, beje, yra vienas iš svarbiausių ir K. Lynčo miesto sandaros metodikoje.

Šiuo metu vyrauja perimetrinis kompaktinis užstatymas, peraugantis ị reprezentacinio užstatymo morfotipo užuomazgas, tačiau be ryškių komplementarių urbanistinių mazgų, kurie tiesiog privalo egzistuoti tokio rango teritorijoje (1 pav.).

Teritorijos ruože tarp Konstitucijos prospekto ir Krokuvos gatvės atskirą dalị sudaro pavieniai, laisvo planavimo principu išdèstyti pastatai, kurie deformuoja anksčiau pradètą formuoti urbanistinị audinị, nebeleidžia susieti erdvinès struktūros su juose esančiais vertikaliais akcentais. Šių vertikalių išdėstymo logikos arba urbanistinès sisteminès motyvacijos nustatyti nepavyko. Kai kurie individualūs suformuoto užstatymo elementai (igilintas „Lietuvos“ viešbučio kiemelis, „Europos“ kvartalas ir „Hanerio“ aukštybinis pastatas), atsiradę egzistavusių vizualinių kanalų ašyse, negrịžtamai sunaikino susiklosčiusios šios miesto dalies urbanistinès sandaros reliktus, hipertrofavo kvartalų dydžius. Aiškiai matyti, kad dabartiniame teritorijos realizacijos etape yra vertinamos ne sisteminès urbanistinio karkaso kategorijos, o vizualinès pasekmès - profesionalių diskusijų objektu tampa tik tai, kaip vienas ar kitas pastatas atrodys iš tam tikrų fiksuotų apžvalgos taškų.

Analizuojant kvartalus išryškèja, kuriose vietose yra deformuoti urbanistiniai kriterijai, kurios zonos yra jau prarastos ir kurias dar galima išgelbèti - „išsaugoti ir praplèsti nuoseklų gatvių modeli - sukurti nedideles, lengvai valdomas atviras erdves - gatvių modelio dalis" (Rodgers, Power 2004), kurios šiuo atveju padètų integruoti teritoriją su visuomeniškai ịprasminta upès apatine terasa.

Teritorijos vakarinèje dalyje vyrauja chaosas. Nuo pat Neries pakrantès iki senosios Krokuvos gatvès neìmanoma ịvardinti naujojo užstatymo pobūdžio.

Urbanistinè netvarka yra ir apatineje upès terasoje. Kalbẻjimas apie viešąsias žalias erdves, vaizdingas upès pakrantes, skverus yra paradoksalus. Negalima teigti, kad čia yra išskirtinė aukščiausio rango visuomeninė erdvè. Iš tikrųjų, tai šioje vietoje iš viso nèra nieko pa- trauklaus, vaizdingo ar visuomeniško. Joje nerasime netgi bandymų sukurti kažkokių išskirtinio architektūrinio pobūdžio bruožų.

Moderniojo miesto centrui formuoti potenciali teritorija yra labai nelygiavertè ir sluoksniuota tiek funkciniu, tiek nuosavybès ir „teisètų privačių bei savininkiškų lūkesčių“ požiūriu. Visas teritorijos ruožas tarp Konstitucijos prospekto ir Krokuvos gatvès neturi ir neturèjo jokių, net ir smulkių visuomeninių erdvių ar bent jų užuominų. Šią problemą galima išspręsti atgaivinant ir prisodrinant renovuojamus vizualinius bei funkcinius kanalus link Neries.

\section{Užstatymo erdvių analizè}

Nagrinëjamoje teritorijoje identifikuojamos tam tikros skirtingo rango mažosios lokalios ir pusiau lokalios erdvès bei didžiosios bendrojo miestinio žaliojo karkaso struktūrinès erdvės (3, 4 pav.). Pastarosios yra aiškiai segmentuotos ir geriausiai identifikuojamos pagal horizontalius erdvių formantus (tiltus). Miesto erdvių požymiai priklauso nuo jų vietos miesto struktūroje. Būtent formuojamos viešosios erdvès, pastatų kompleksai, jų bendra aplinkos kokybė demonstruoja kultūrinị miesto potencialą (Daunora 2005).

Miesto bendrojo plano sprendiniuose (Vilniaus... 2007) abieju Neries krantų integracijai yra pasiūlytos dvi galimos naujo tilto, jungiančio dešinijj krantą su Kernavès gatve, trasos versijos: „Kreivasis“ tiltas ir tiltas ties Mečetès gatvès tęsiniu. Beje, tradicinè bet kurio miesto istoriškai susiformavusi upès ir užstatymo organiško ryšio urbanistinè sandara yra paremta statmenai i upę orientuotais ryšiais (vizualiniais kanalais) ir tam pavaldžia organizacine struktūra.

A variantu (2 pav.) struktūrinès ašys, užtikrinančios abiejų krantų funkcinị ir vizualinị integralumą, nebetektų savo pirmapradès prasmès. Žaliojo karkaso erdvès neleistinai deformuotųsi - tarp Baltojo ir „Kreivojo“ tiltų užsispaustų i pleištą, o link Geležinio Vilko tilto taip išsikreivintų, kad taptų nebenusakomų parametrų. Aiškiai matyti, kad šis tilto variantas savo pasekmèmis visapusiškai prieštarautų Vilniaus urbanistinès struktūros sampratos logikai, vadinamai identitetu.

B variantu toliau nuosekliai būtų vystomas suformuotas gatvių tinklas. Vizualinių ir funkcinių kanalų tąsos abiejuose krantuose logiškai jungtųsi tiltu Mečetès gatvès tęsinyje, formuodamos racionalias, normalias ir suprantamų matmenų parterio struktūrines erdves, kurioms pagal diktuojamą formuojamos aplinkos prioritetą turi būti skirtingai taikoma ir erdvių ịprasminimo architektūrinè instrumentuote. Igauna pras- 


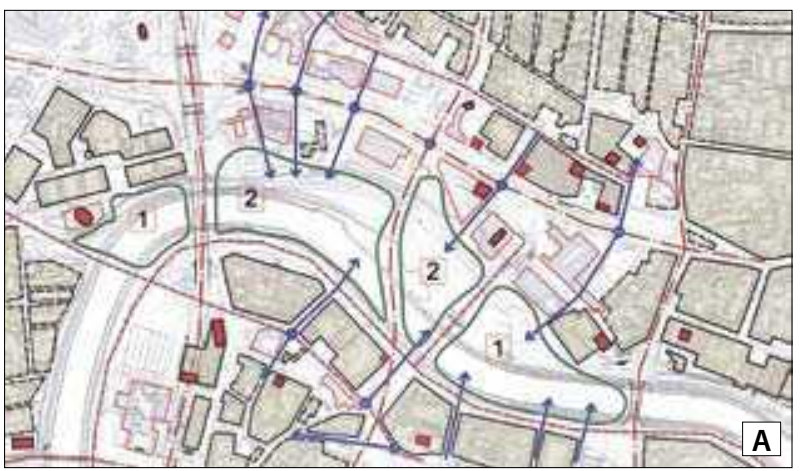

2 pav. Žaliojo karkaso struktūrinès erdvès ( $A, B$ variantai)

Fig. 2. Structural areas of the Green Framework (A, B variants)

mę pagrindinès struktūrinès ašys - Konstitucijos pr., Lvovo ir Krokuvos bei Kernavès gatvès, svarbūs ir vertingi vizualiniai kanalai (daugiausia istoriniai, turintys išliekamąją vertę teritorijos urbanistinio genofondo išsaugojimui), aktyvūs vienpusio arba abipusio kontakto struktūriniai požymiai, kuriuos vertètų išsaugoti ir akcentuoti.

Lyginant su „Kreivuoju“ tiltu, dešiniojo kranto jungtis ties Mečetès gatve užtikrintų minimalų ir dvigubai trumpesnį tilto ir pačios trasos ilgị. Ivvertinant tai, kad jungties tąsoje yra galima esamo kalejjimo teritorijos konversija ị naują urbanistinį mazgą su papildomais transporto srautais, toks trasavimas būtų daug prasmingesnis. Visai netoli būtų ir Gynejjų gatvès šviesoforais reguliuojama sankryža, kad dar viena papildoma trasa bei Geležinio Vilko gatve (dešiniaisiais posūkiais) leistų patogiai susisiekti su miesto centru - Gedimino prospektu. Ateityje visoje Lukiškių gatvès trasoje tektų irengti dvipusį eismą. Esama Mečetės gatvès važiuojamoji dalis ir jos raudonosios linijos nesukelia problemų tokiai jungčiai įrengti.

„Vilniaus miesto centrinès dalies reglamentas turètų remtis gamtinès ir urbanistinės morfostruktūros ypatumais bei vertingiausių jos elementų įvaizdžio apsauga, kurią atspindètų šie teiginiai:

- Išskirtinis ịvaizdžio bruožas yra didelè miestovaizdžiu ịvairovè, aiškiai besiskirianti kvartalų užstatymo pobūdžiu, užstatymo aukštingumu, santykiu su gamtinès morfostruktūros elementais, aukštybinès plètros sąlygomis.

- Aukštybinių pastatų fiziniai parametrai neturètų niveliuoti egzistuojančios miestovaizdžių ịvairovès.

- Aukštybinių pastatų įterpimo galimybes apibrèžia vizualinị identitetą lemiančių struktūrinių miesto

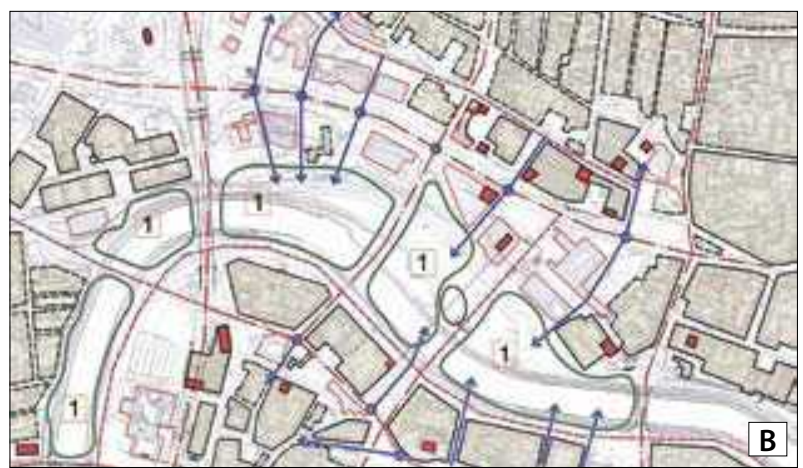

elementų hierarchiją atitinkantys apsaugos principai.

- Centrinès sostinès dalies urbanistinès plètros idèjos neturètų keisti gamtinès ir urbanistinès morfostruktūros, jos turètų ją stiprinti ir semantizuoti“" (Daunora 2003).

Žemutineje upès terasoje, aktyviausioje dinaminèje apžvalgos panoramoje (A. Goštauto gatvès trasoje) nustatyti apžvalgos taškai (3 pav.), kuriuose vizualiai skirtingai suvokiamas užstatymo aukštingumas ir pobūdis. Šie veiksniai lemia skirtingą poveikị ir ịsipareigojimus formuojamiems naujiems urbanistiniams kompleksams, skirtingiems užstatymo morfotipams bendrojoje struktūroje.

Pirmiausia tai apžvalgos taškai, iš kurių galima objektyviai nustatyti takoskyrą, kurioje dèl esamo užstatymo fizinio poveikio nebetenka prasmès tolimojo gamtinio fono saugojimas. Tai sektorius ị vakarus nuo buvusio Kolūkių projektavimo instituto iki žaliojo „Hanerio“ pastato. Čia būtina reglamentuoti ribines galimo naujo užstatymo altitudes, aukščių skirtumo amplitudę priskiriant tam tikriems fiksuotiems formuotino užstatymo planams.

Lokalių erdvių analizès išvados (4 pav.) aiškiai parodo fiksuotus ruožus ir teritorinius segmentus (erdvių persidengimuose ar sąlyčio taškuose), kuriuose būtina formuoti naują, trūkstamą užstatymą ir taip užbaigti realizuoti urbanistinị audinị.

Galima pagrịstai teigti, kad siekiant susisteminti naujojo centro urbanistinę visumą, kritinę masę bei integralumą Šnipiškių ir kairiojo Neries kranto kontekste, privaloma:

1. išsaugoti, o statant tiltus ar rekonstruojant stambesnius objektus bei kompleksus, sutvarkyti ir iprasminti urbanistinio ir gamtinio karkaso struktūrines erdves ir vizualinius kanalus. Tam tikrais 


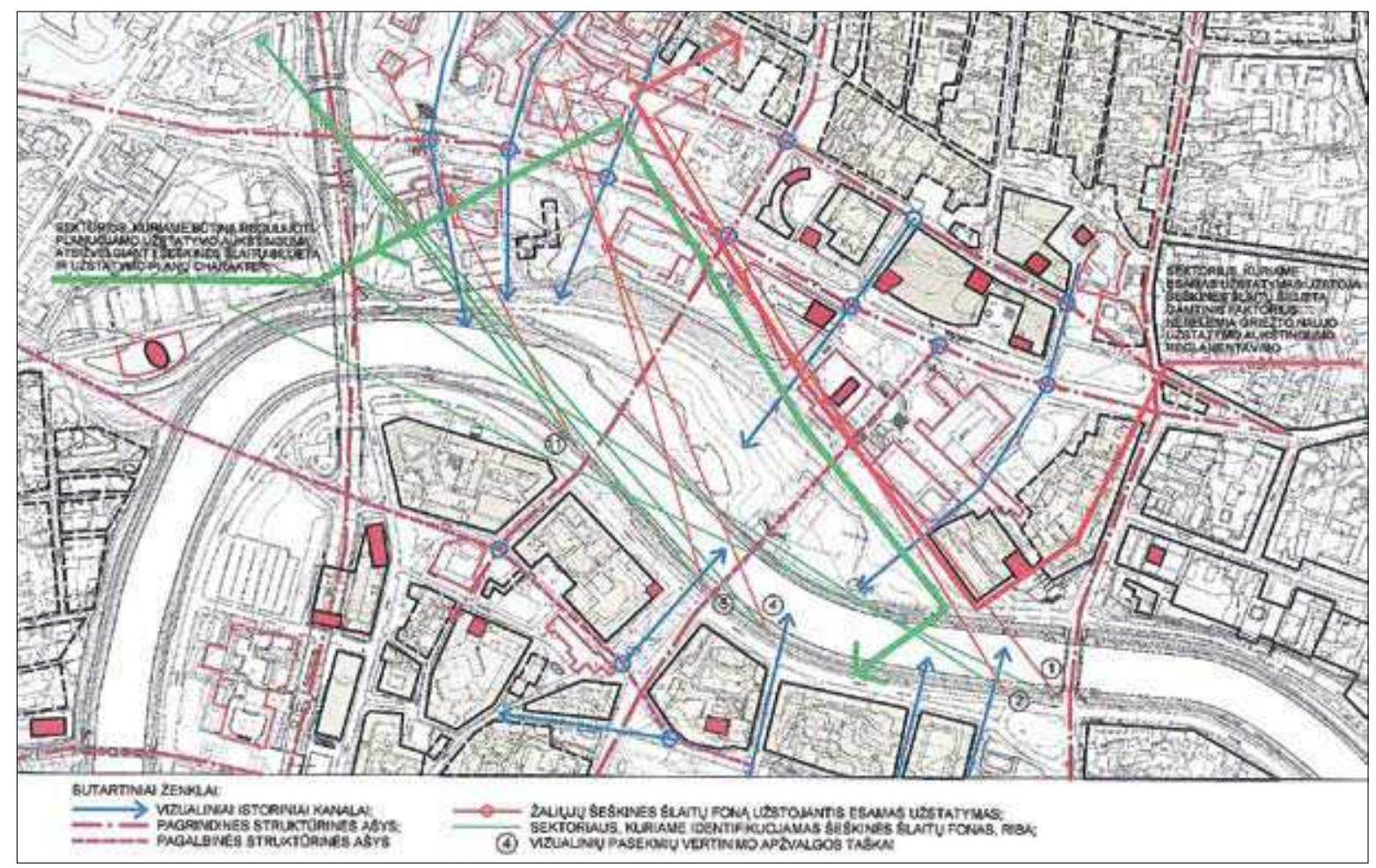

3 pav. Vizualinių pasekmių prognoze iš žemutinès terasos apžvalgos taškų

Fig. 3. Prognosis of visual outcome from the viewpoints of the lower terrace

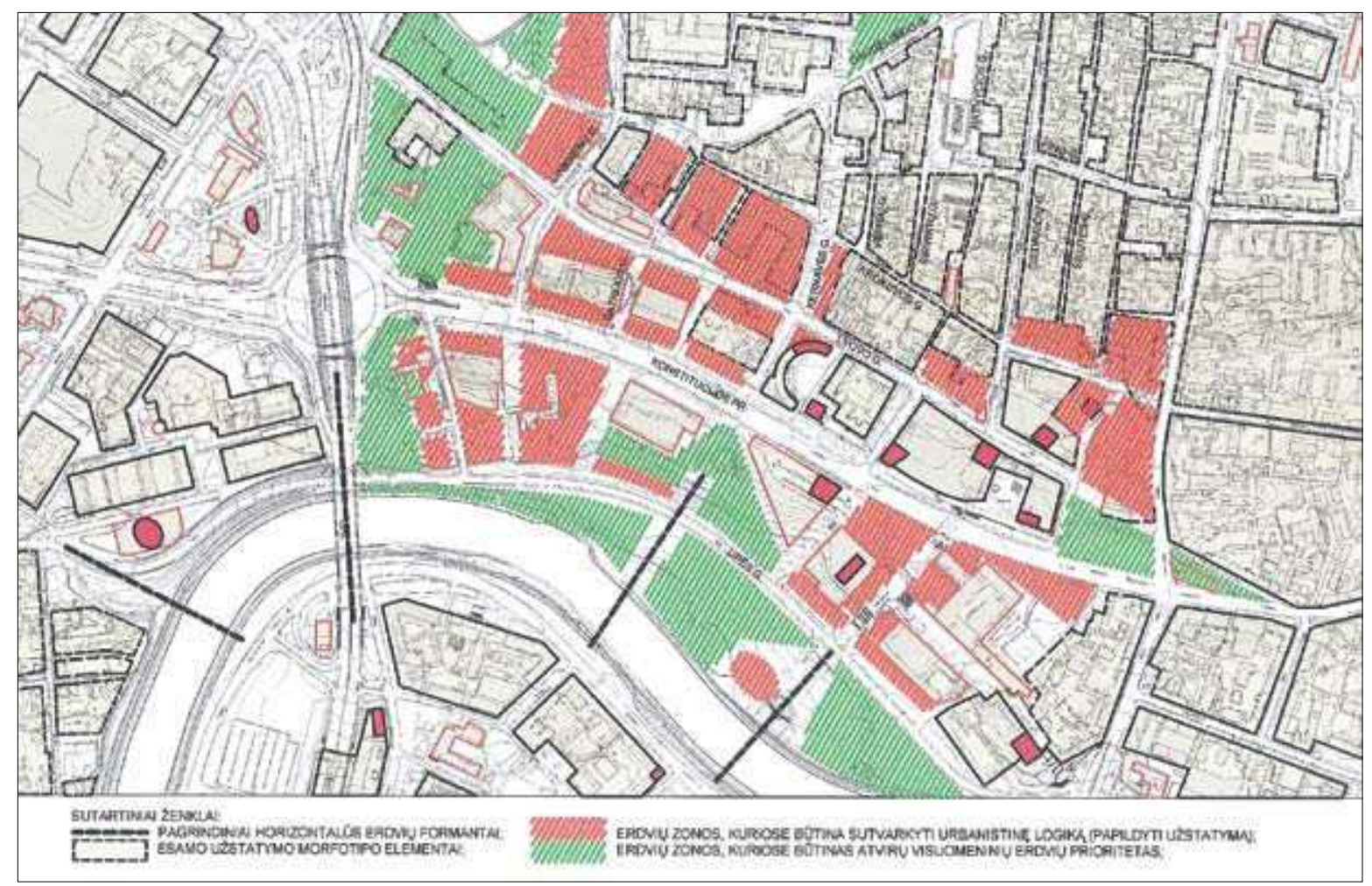

4 pav. Lokalios erdvės ir jų rekonstrukcijos principai

Fig. 4. Local areas and their reconstruction principles 
atvejais tikslinga netgi atkurti dabartiniu metu jau nebeegzistuojančius, bet sistemiškai prasmingus vizualinius ryšius.

2. Užtaisyti spragas lokaliose erdvèse Konstitucijos prospekto aplinkoje, suteikiant aiškias tų erdvių apybraižas ir, pratęsiant reguliariąją struktūrą, akcentuoti tų erdvių ryšius su upès apatine terasa;

3. Nustatyti priemones esamam stichiškam užstatymo pobūdžiui suvaldyti:

- apibrežti formuojamos „architektūrinès kalvos“ parametrus;

- reglamentuoti užstatymo planų aukštingumo kitimo logiką;

- ivardinti urbanistines priemones teritorijai struktūrizuoti.

4. Nustatyti optimalius planuojamų kvartalų dydžius tiek planiniu, tiek užstatymo aukštingumo požiūriu Neries apatinejje terasoje (parteryje) ir siūlomo užstatymo formavimo sistemos požymius, ịvertinant ir panaudojant reljefo perkritimus užstatymo dinamikai išryškinti:

- kvartalu pietinès užstatymo kraštinès turètų atsirasti reljefo lūžio taške virš apatinès parterio terasos Upès gatvès perimetro ribose;
- išskirtinė pietinès išklotinès mažo užstatymo aukštingumo pastatų funkcija - tik viešam interesui (aptarnavimas, maitinimas, smulki prekyba), tai užtikrintų urbanistinès struktūros vientisumą ir garantuotų pilnavertę ir gyvybingą viešųjų erdvių funkcinę realizaciją.

5. Nustatyti kvartalų morfotipo pobūdį aukštutinèje terasoje ị šiaurę nuo Konstitucijos prospekto, t. y. turi būti nustatytas kvartalo tipas pagal atsiradusi naują užstatymo principą - stereobatas su vertikaliniais akcentais (bokštais) arba stereobatas su nelabai aukštais, daugiau ištęstais horizontaliais viršutiniais tūriais.

\section{Teritorijos vizualinių pasekmių vertinimas}

Teritorijos vizualinei analizei optimizuoti panoramų atranka buvo atlikta iš miesto bendrajame plane nurodytų ir kitų prasmingų apžvalgos taškų (5 pav.).

Žvelgiant nuo Gedimino bokšto (A panorama) niveliuojasi užstatymo planai, neįmanoma identifikuoti komplekso planinès struktūros atitikmenų, esant horizontaliam masteliui transformuojasi tikrieji dydžiai. Dèl „Lietuvos“ viešbučio, stovinčio Šv. Rapolo bažnyčios fone, „architektūrinès kalvos“ matomumo zonoje
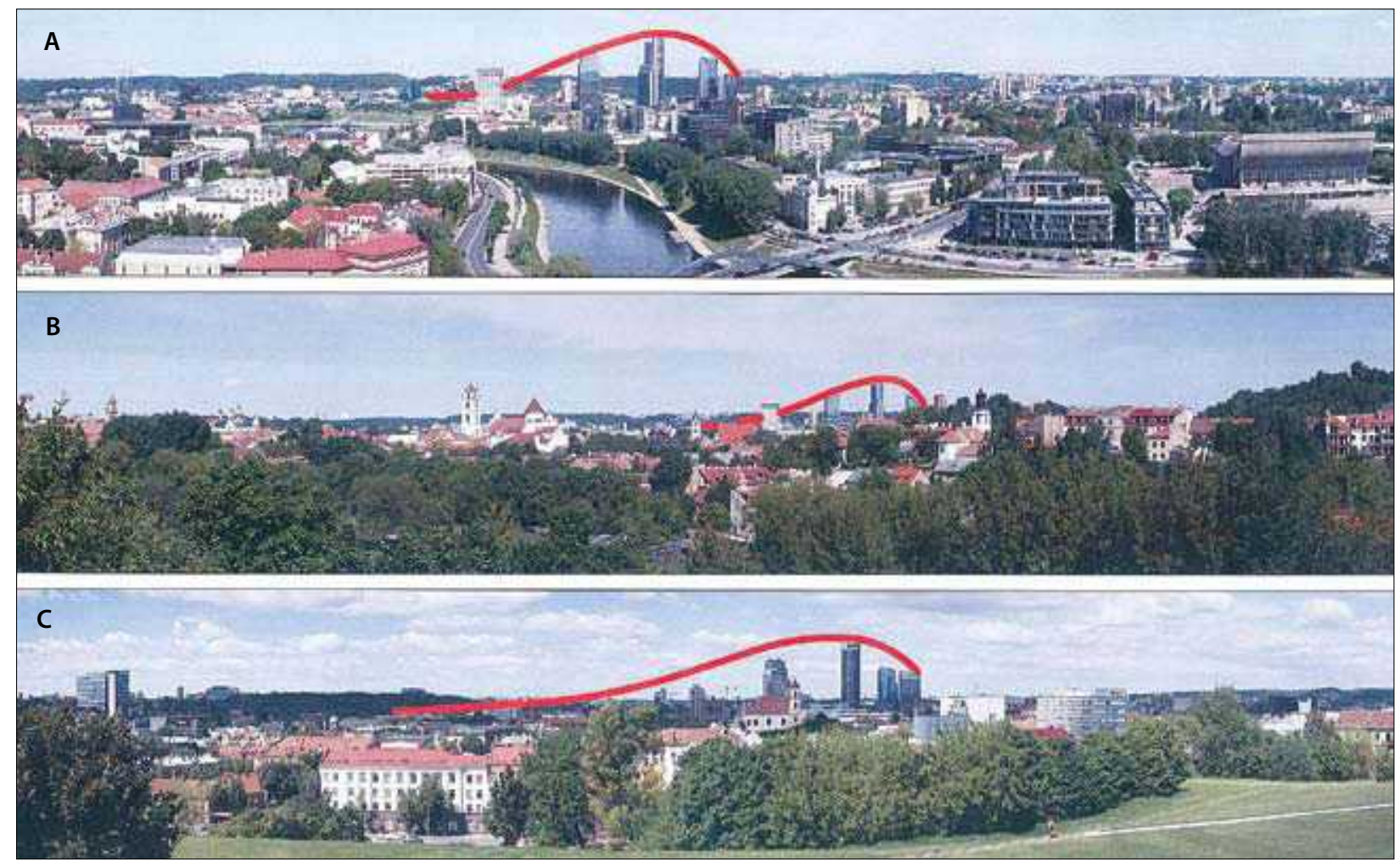

5 pav. Vizualinès analizès atranka $(A, B, C)$

Fig. 5. Selection of visual analysis $(A, B, C)$ 
vizualiai hipertrofuojasi fiziniai užstatymo parametrai. Galima konstatuoti tik tai, kad formuojamoje „architektūrinèje kalvoje" būtina didinti užstatymo tankị.

Subačiaus gatvès apžvalgos aikštelè (B panorama) yra per toli. Iš jos geriausiai matomos senamiesčio panoramos ir kiti artimesnieji planai. Žaliụjų Šeškinès kalvų masyvas jau slepiasi už esamo užstatymo.

Objektyviausiai apie moderniojo centro parametrus galima spręsti iš Tauro kalno viršutinès terasos apžvalgos aikštelès (C panorama). Šiame taške kuriamą centrą mažiausiai užstoja artimieji užstatymo planai, frontaliai projektuojasi tikrieji planiniai dydžiai ir vertikalès, aiškiausiai suvokiamas užstatymo daugiaplaniškumas, išryškèja vizualinių kanalų ašys.

Urbanistinès analizès išvados - tai kriterijai, kurie neišvengiamai veikia planuojamos teritorijos urbanistinius sprendinius ir duoda argumentuotus paaiškinimus galimoms planuojamo urbanistinio komplekso interpretacijoms. Darosi aišku, kad Konstitucijos prospekto pietineje išklotinejje turi dominuoti užstatymas, o ne pavieniai stovintys pastatai, kurie negali fiziškai suformuoti Konstitucijos prospekto išklotinès, suteikti viešojo intereso bruožų gatvès erdvei, netgi negali užtikrinti paupio terasos pilnaverčio integralumo, numatant galimus visuomeninių erdvių funkcinius scenarijus, kaip padidinti miestelènų lankomą ir patrauklumą.

\section{Urbanistinès struktūros koncepcija}

\section{Užstatymo aukštingumo pagrindimo strategija}

Nustatyta nagrinejjamos teritorijos padètis bendrojo miestinio urbanistinio ir žaliojo karkaso struktūrinių erdvių sistemoje. Identifikuoti viršutinès terasos išlikę šlaitų fragmentai, kurie yra vieni iš vertingiausių miesto savitumo išraiškos elementų.

"Gamtiniai elementai ir gamtinių architektūrinių elementų dariniai Vilniaus centro erdvineje struktūroje igyja vizualinès kompozicijos reikšmes. Neries upès slènis bei jo žalieji šlaitai łgyja aukščiausią miesto centro erdvinès struktūros kompozicinio karkaso reikšmę <...>. Pilies kalnas - kompozicinis centras, Triju Kryžių ir Bekešo kalnas, Šeškinès kalva, Pamènkalnio plynaukšte - kompoziciniai pocentriai“ (Daunora et al. 2004).

Kuriamas naujas miesto centras yra išskirtinejje geografinèje padètyje, kuri griežtai nulemia šio bendrojo miestinio komplekso fizinius parametrus. Imant atskaitos taškais minètas ryškiausias istorinį miestą supančias kalvas kaip gamtinio savitumo chrestomatines gaires, labai aiškiai identifikuojamas galimas „,archi- tektūrinès kalvos", kaip kompozicinio miesto audinio komponento, kritinis dydis ir potenciali jo vizualinè reikšmè.

„Architektūrinę kalvą“ vakarinèje dalyje galima pradèti auginti nuo 25 laipsnių sektoriaus, žiūrint iš Tauro kalno apžvalgos aikštelès (6 pav.). Šiame sektoriuje nuo Alt.138,0 vakarų kryptimi dar yra visiškai matomas ir struktūriškai identifikuojamas palaipsniui žemëjantis Vilniaus urbanistinị identitetą reprezentuojančio Ozo žaliojo masyvo kontūras ir Baltupių rajono užstatymo pradžia. Žaliojo fono vizualinio vientisumo išsaugojimas yra pagrindinė sąlyga siekiant apsaugoti apatinę terasą nuo „urbanistinès patvankos“, kuri neišvengiamai gresia bandant didinti aukštingumą ir „architektūrinès kalvos" apimtị plane.

25 laipsnių apžvalgos žymoje maksimalaus užstatymo kreivè pasiekia Alt. 141,0. Ši riba yra faktiška „architektūrinès kalvos“ pradžia (papèdè) vakarinèje centro dalyje.

Kalvos papèdes, viršūnę ir svarbiausius planinès struktūros taškus tikslinga akcentuoti išskirtinèmis architektūrinès išraiškos priemonèmis - smailèmis, kurios savo matmenimis proporcingai būtų mažesnès už frontalines aukštutinių dalių fasadines projekcijas.

Kompleksiškai vertinant prognozuojamas vizualines pasekmes iš žemutinių ir aukštutinių chrestomatinių apžvalgos taškų, galima tiksliai nustatyti ir nurodyti sektorių, kuriame būtina apriboti galimo užstatymo altitudes nuo 116,0 iki 138,0 m. Aukščių skirtumo amplitudę derètų išskaidyti fiksuotais laip-

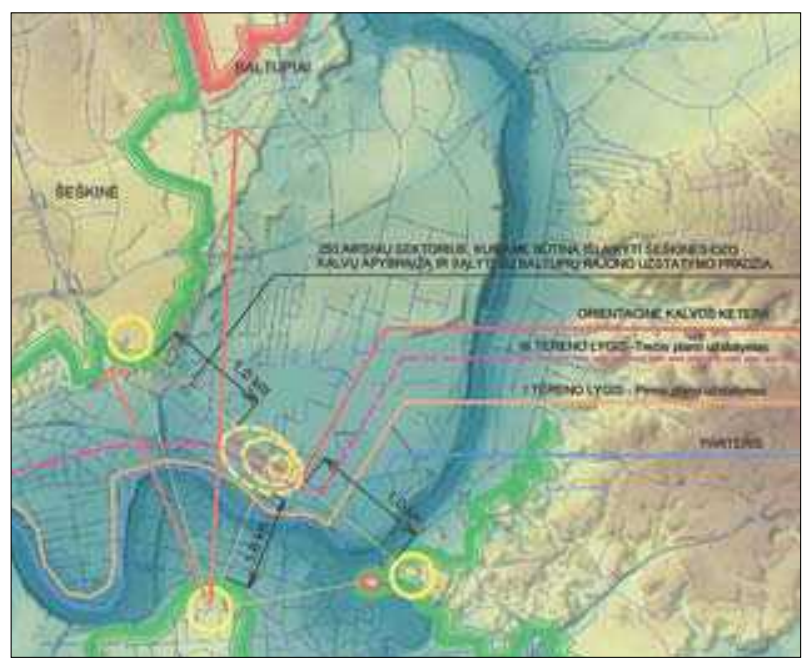

6 pav. "Architektūrinès kalvos" parametrų ir struktūros daugiaplaniškumo geografinè logika

Fig. 6. Geografic logic of parameters and multi-layer landscape structure of "urban hill" 
tais (terasomis) ir priskirti juos tam tikriems naujo užstatymo planams. Šiame sektoriuje tektų riboti antros reljefo terasos užstatymo aukštị ir imti taikyti dar vieną tarpinị (žemesnị) formuotiną užstatymo planą.

Toliau, rytų kryptimi turètų dinamiškai pradèti augti užstatymo aukštis ir intensyvumas, kuris, pasiekęs aukščiausią tašką zonoje tarp Ratnyčios ir Giedraičių gatvių, staigiai žemėdamas baigtų „,architektūrinès kalvos" fizinę apimtị ties 8 Kalvarijų gatvès vizualiniu kanalu.

\section{Planinès struktūros plètojimo kryptys}

Vertinant išryškintus struktūrinius motyvus, labai svarbu i bendrą kompozicinę visumą sutelkti Neries žemutinès terasos struktūrines erdves, peraugančias i bendrą urbanistinę kompoziciją.

Kiekvienai reljefo terasai (7 pav.) derètų turèti savita užstatymo plano apybraižą. Pirmiausia turètų būti formuojamas parteris, t. y. apatinè terasa. Paskui - aukštesnieji užstatymo planai iki Konstitucijos prospekto išklotinès. Šiame ruože yra ryškiausi žemès paviršiaus šuoliai. Todèl čia turètų atsirasti bent du užstatymo aukštingumo planai - papildomas (tarpinis) bei antra- sis užstatymo planas, formuojantis Konstitucijos prospekto pietinę kraštinę. Toliau eitų trečiasis užstatymo planas - Konstitucijos prospekto šiaurinès išklotinès formantas ir galiausiai - maksimalaus aukščio ketera ruože tarp Lvovo ir Krokuvos gatvių.

Struktūrinių žalių erdvių, galinčių veikti miesto individualumą, geografija ir esamo užstatymo fragmentai diktuoja tam tikras sąlygas skirtingai šių erdvių realizacijai ir funkcijoms, nes upès kaip pagrindinès gamtinès ašies integracija ị sostinès centro urbanistinę struktūrą yra vienas iš svarbiausių moderniojo centro modelio kūrimo uždavinių (8 pav.).

Parteris yra bene svarbiausia ir sudètingiausia urbanistinio komplekso dalis - tai pamatas, kurio išraiška ir stilistika lems viso darinio kompozicinį vientisumą. Dabar šis pagrindas tèra išskydęs draikalas, neturintis jokios prasmingos išraiškos, nekalbant jau apie sostinès ìvaizdị. Šiuo metu čia dominuoja techniniai pastatų fasadai ir automobilių stovejjimo plotai. Matyt, parterinis užstatymas neišvengiamai turi būti humanizuotas ir imti atitikti kiek įmanoma daugiau visuomeninių interesų. Tą ígyvendinti galima likviduojant automobilių stovejjimo aikšteles ir papildant esamą užstatymą iki

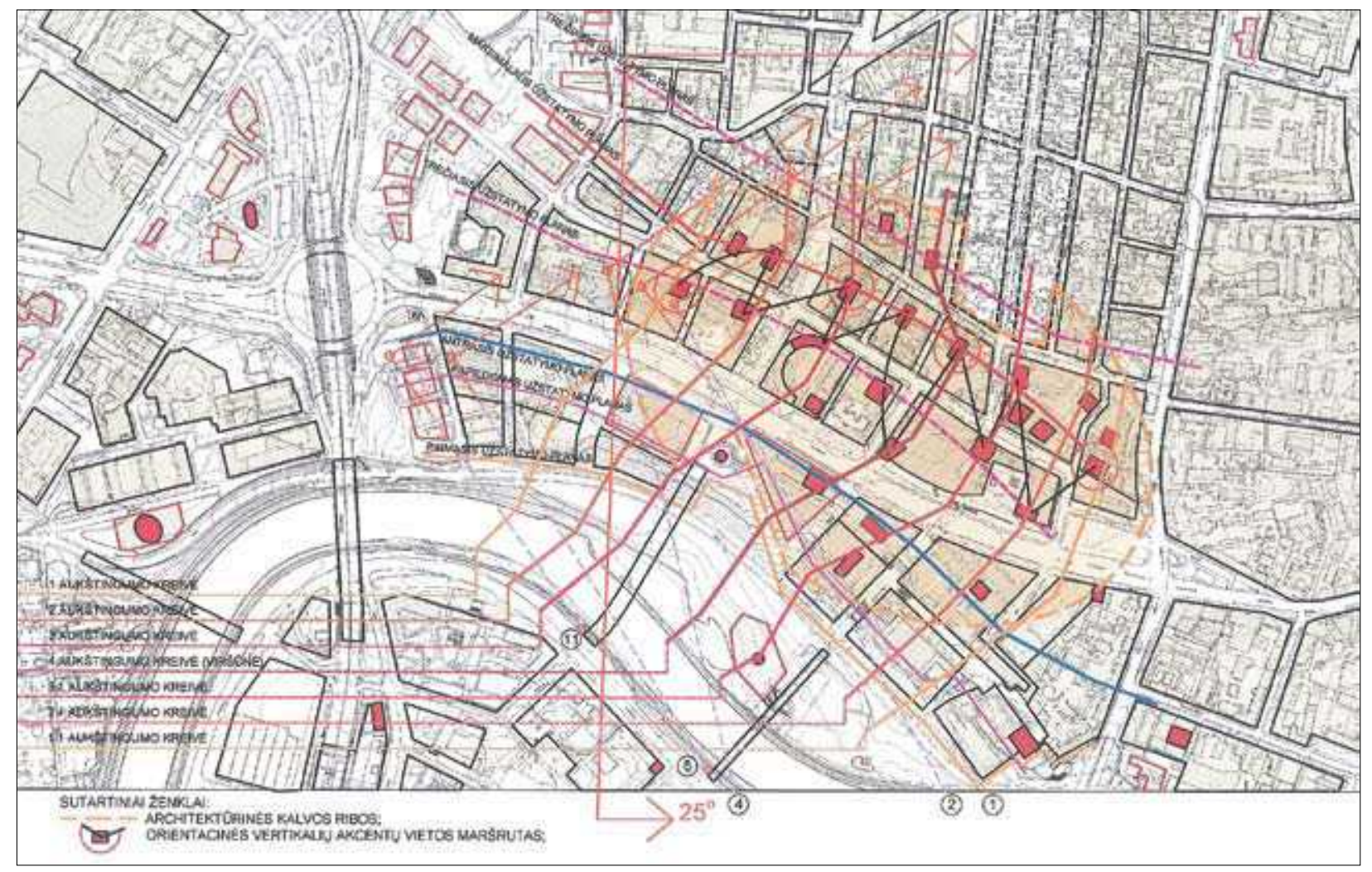

7 pav. Užstatymo aukštingumo planai (terasos)

Fig. 7. Height layers of urban landscape (terraces) 
normalaus perimetro VCUP ir "Lietuvos“ viešbučio stilobatinèse dalyse bei papildant neaukštu perimetriniu užstatymu vakarinę parterio dalị link Geležinio Vilko tilto. Tuo labiau kad dabartinio „Forum palace“ pastato stilobatinè dalis jau ir taip turi neišvengiamus perimetrinio užstatymo bruožus.

Pirmoji struktūrinè erdvè - reguliaresnè, uždaresnio pobūdžio funkciškai aktyvuota erdve tarp Geležinio Vilko ir naujai projektuojamo tilto Mečetès gatvès tąsoje su centruota upès vaga (8 pav.). Jos šiauriniame fronte, kur per išlikusių vizualinių kanalų ašis nusileidžia kvartalinis užstatymas, peršasi vienintelè logiškiausia perimetrine mažo aukštingumo užstatymo išklotinè, vizualinių kanalų suskaidyta ị trumpus ruožus ir skirta visuomeninei traukai sustiprinti. Perimetras sẻkmingai derètų su dešinèje upès krantinèje jau egzistuojančiu frontaliniu užstatymu. Aišku, užstatymo mastelis ir estetinis ịprasminimas turètu būti labai jautrus ir atsakingai parinktas. Šioje vietoje su užstatymo išklotine, išlyginančia esamą šešiu metrų žemès paviršiaus šuolị, ko gero, būtina įrengti žalius eksploatuojamus stogus, uždengiančius neišvengiamas automobilių saugyklas, o priekinị planą užleisti išimtinai viešam interesui. Formuojamoje išklotinejje svarbu nepažeisti Nacionalinio muziejaus ịvaizdžio. Akivaizdu, kad siekiant išsaugoti jo unikalią urbanistinę traktuotę, parterio užstatymo įvaizdis tegali būti sutapatintas su funkciškai ịprasminta atramine siena, pereinančia į žalią šlaito ruožą, užstojantị ūkinị kiemą.

Antroji - visiškai kitokio pobūdžio, pusiau atvira struktūrinè upès erdvè (8 pav.). Ji yra visiškai neaiškios geometrijos, nusmailèjanti sakurų skverelio perimetru ir pasibaigianti ties jau simboline „Pirmųjų kregždžių“ skulptūra. Vienintelè kompozicinė priemonè šiai problemai išspręsti ir struktūrizuoti trūkstamą erdvinị balansą - Mokslininkų namų ir „Lietuvos“ viešbučio vertikalių linijoje, pabrèžiančioje labai svarbią struktūrinę aši, integruoti savarankišką, erdvèje išcentruotą architektūrinę masę. Toks būdas leistų sujungti dvi greta esančias erdves, ịprasminti masteliškumą ir atkurti pamestą erdvinį balansą.

Trečiasis erdvès tipas yra atvira erdvė (8 pav.). Šioje situacijoje šiaurinis perimetras suformuotas istorine vienuolyno komplekso išklotine, pietinis - užbetonuotu upès šlaitu ir medžių alejja kairiajame krante. Ši

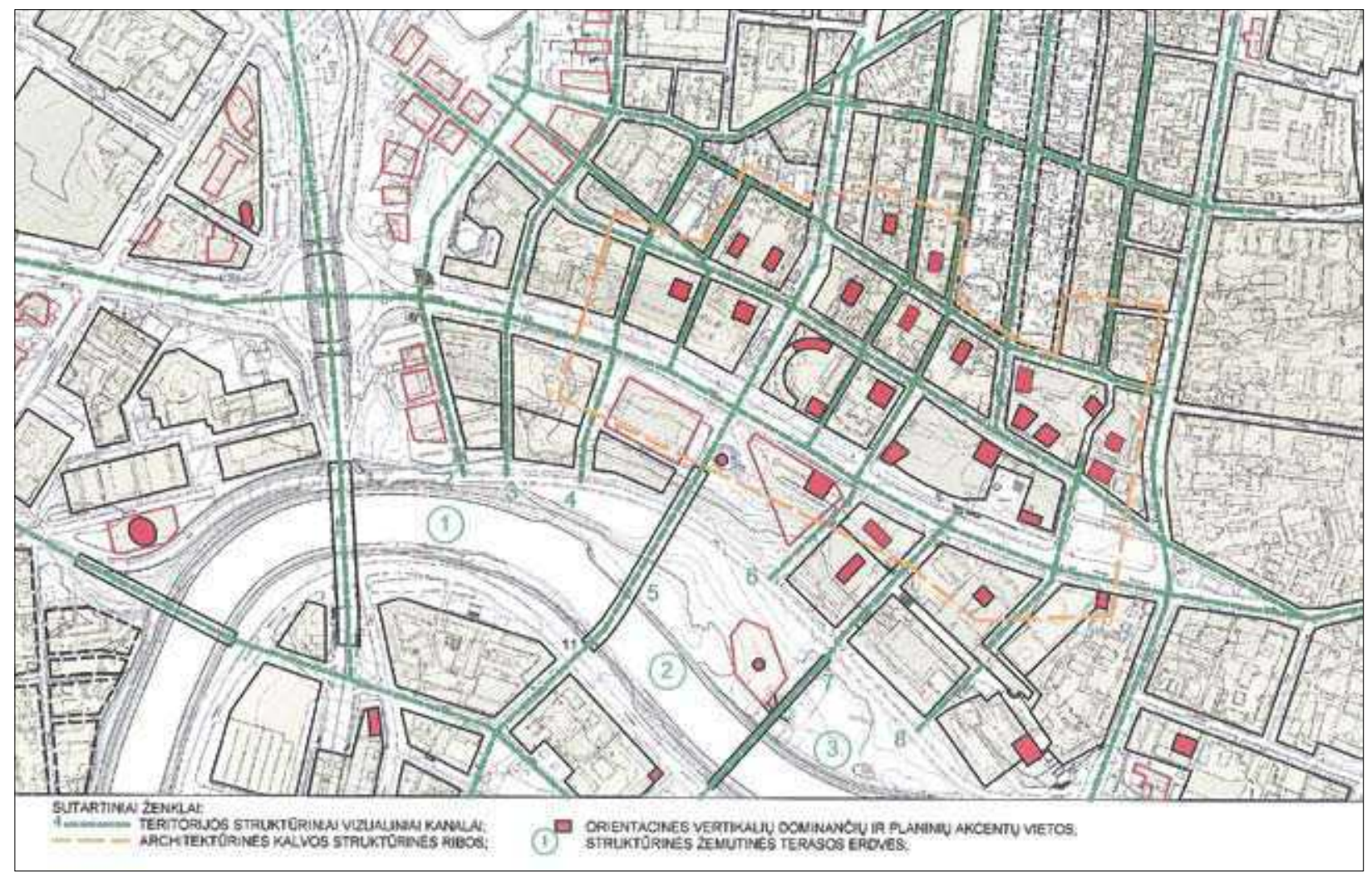

8 pav. Užstatymo planinè struktūra

Fig 8. Planned structure of built-up areas 
struktūrinè erdvė galètų būti formuojama smulkiais želdinių fragmentais, su Baltojo tilto link kylančiu terenu, kuris vizualiai uždarytų nesąmoningą plyši tarp tilto horizontalès ir parterio.

Kompozicinis tūrinis kalvos kompleksas (kupolas) igauna maksimalias ribas tarp Šatrijos ir Kalvarijų gatvių. Kalvos pradžia (papèdè) vakariniame kontūre praeina pietine Krokuvos gatvès užstatymo išklotine ir baigiasi Kalvarijų gatvės kontūru rytinèje centro dalyje. Pietinis kalvos šlaitas yra sunkiai identifikuojamas, nes esami nestruktūriniai pastatai ir deformuotos erdvès („Lietuvos“ viešbutis bei „Hansabankas“) nebeleidžia užbaigti formuoti pilnavertį urbanistinị kompleksą. Tačiau statybinius tūrius tarp pirmojo ir antrojo užstatymo planų sugrupavus pagal terasų struktūrą ir sutvarkius parterį, užstatymo planų išklotinèse atsirastų nuoseklus užstatymo kilimas šiaurès kryptimi link kalvos keteros.

Kvartalų dydžiai nustatyti atsižvelgiant į Šnipiškių urbanistinès struktūros planinių elementų apimtị ir ritmą. Panaudojant esamą urbanistinị genofondą, sudaromos prielaidos naujai kompozicinei vertei sukurti. Kvartalai suvokiami kaip stilobatai, turintys bendrą architektūrinę kompoziciją vietovès urbanistinio tinklo hierarchijoje. Šiuo metu propaguojamas modelis, pasižymintis žemesne stilobatine dalimi ir vertikaliais akcentais, išreikštais pačiose fasadų išklotinèse. Šis morfotipas visiškai nebūdingas Vilniui. Jis kaip šiuolaikinès mados išraiškos pasekmė be jokio kontekstualumo atėjo iš architektūrinių žurnalų puslapių. Pagal dominavimą virš stilobatinès dalies vertikalios dominantės (aukščio akcentai) turètų atsirasti kvartalų vidinèse dalyse atitrauktos nuo vizualinių kanalų plokštumų.

\section{Užstatymo pobūdis ir aukštingumas}

Teritorijos užstatymo aukštingumo ir daugiaplaniškumo priklausomybè nuo teritorijos reljefo terasuotumo yra įvertinta nustatant projektuojamus užstatymo planus ir jų vietą struktūrinejje hierarchijoje.

Parterio perimetras - pirmojo užstatymo plano aukštingumas neturètų viršyti 105,0 altitudès.

Papildomas užstatymo planas (apie 100,0 Alt.) turètų būti tarpinis, švelninantis staigų per aukštą užstatymą iki Konstitucijos prospekto išklotinès. Čia užstatymas tolygiai kiltų nuo 113,0 Alt. vakarinèje dalyje (ties dabartinemis „Forum Palace“ atviromis automobiliu stovèjimo aikštelèmis) iki 128,0 Alt. VCUP užstatymo sektoriuje.
Antrasis užstatymo planas yra Konstitucijos prospekto pietinę išklotinę formuojantys pastatai. Jo ribinis aukštingumas be žalos panoramoms gali prasideti 127,0 altitude virš „Forum Palace“ pastato ir pakilti iki 135,0 altitudès gretimame sklype.

Trečiasis užstatymo planas - Konstitucijos prospekto šiaurinès išklotinès formantas. Šiame ruože jau dabar yra pagrindinè aukštybinių pastatų sankaupa. Tai maksimalaus užstatymo kreives pagrindas, kuriame formuojasi „architektūrinès kalvos“"ketera. Vakarinis kalvos šlaitas pagal esamus ir suprojektuotus pastatus yra lèkštesnis, palaipsniui kylantis link viršūnès, kurios maksimalus aukštis (viršūnè) galètų pasiekti 240,0 altitudę.

Vertinant šio ruožo planinius parametrus ir jau esamus bei suprojektuotus pastatus, yra galimybė pagrịsti maksimalaus užstatymo aukštį. Planuojamos maksimalaus aukštingumo kreives (keteros) altitudès kyla iš palaipsniui aukštejjančių žemesniųjų užstatymo planų konstrukcijos. Tai reiškia, kad bet kuri aukštingumo kreivès frontalinè pozicija turi savo tikslią vietą plane. Ši kreivè turètų būti privaloma linija, kurią, analizuojant atskirų kvartalų užstatymo galimybes (urbanistini modelį), reikia pasiekti, bet negalima viršyti, nes:

1. Maksimalaus užstatymo linija yra optimizuota kreivè (9 pav.), nubrěžta remiantis:

- urbanistine planuojamos teritorijos analize;

- motyvuotais objektyviais veiksniais - realiomis esamų ir suprojektuotų pastatų altitudemis;

- urbanistinèje analizejje pagrịsta fizine kalvos apimtimi;

- nustatytu sektoriumi, kuriame būtina išlaikyti ir nepažeisti vizualinio Šeškinès bei Ozo kalvų ir Baltupio rajono užstatymo santykio.

2. Šioje linijoje (4 sektoriuose: dviejose kalvos papèdèse, kalvos viršūnėje ir užstatymo morfotipo pokyčio vietoje - Šatrijos gatvès vizualiniame kanale) turi atsirasti išskirtinès architektūros urbanistiniai akcentai (viršūnès).

Stilobatinių dalių santykis su galimų vertikalių akcentų aukščio kriterijais turi būti nustatomas kiekvienam konkrečiam kvartalui, remiantis egzistuojančia ir šiam konkrečiam urbanistiniam atvejui tinkančia metodika (Vyšniūnas 2003).

Teritorijos užstatymo aukštingumas ir jo pobūdis buvo ir yra skirtingų suinteresuotų tiesų įrodinèjimo objektas. Daugelis šių pozicijų vienaip ar kitaip remiasi konkrečiais darbais, projektais ar publikacijomis. Jas apibendrinus galima išskirti šešias charakteringas al- 

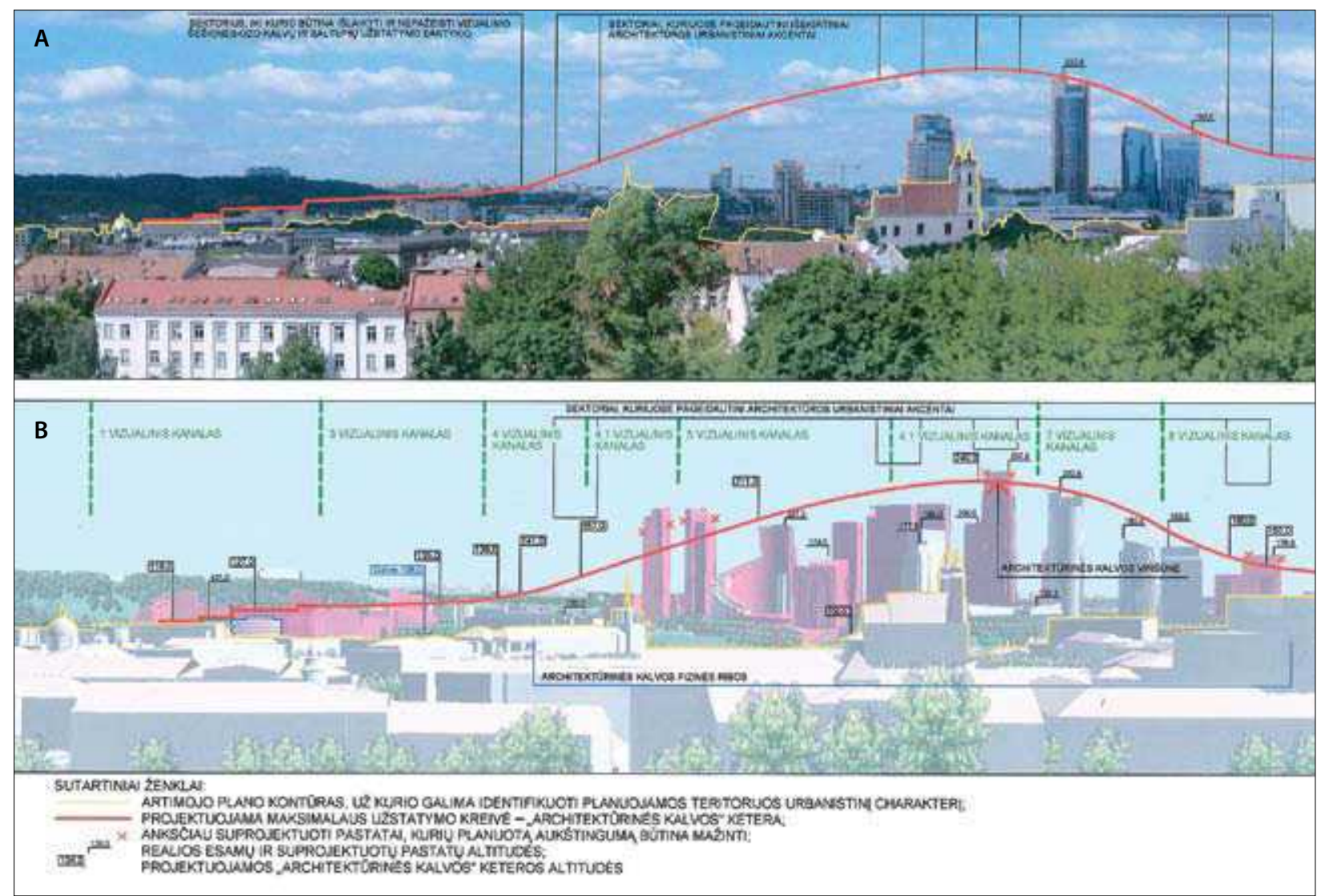

9 pav. Maksimalaus aukštingumo kreivès modelis: A - esamos būklès kontekste; $B$ - planuojamoje situacijoje

Fig 9. Model of curve for maximum height: $A$ - existing situation; $B$ - planned situation

ternatyvias grupes (10 pav.). Jos vizualiai sugretintos su šiame darbe siūloma optimizuota maksimalaus aukštingumo kreive (raudona linija).

Akivaizdu, kad galiojančioje Šnipiškių rajono plètojimo raidos programoje (Šnipiškių... 2005) nustatytas aukštingumo reglamentas šiek tiek chaotiškas ir nelabai išryškina siektiną daugiaplaniškumą (1 kreivè). Nepakankamai konceptualus struktūriniu požiūriu upès apatinès terasos formavimas, neịvertintas dinamiškas "architektūrinès kalvos" augimas, nes ruože tarp „Forum Palace“ ir „Hansabanko“ nustatytas pastovus 10 aukštų (iki 141,0 Alt.) užstatymas. Kelia abejonių „architektūrinis kupstas“ senvagèje.

2006 m. aprobuoti „Vilniaus kultūrinių urbanistinių draustinių komplekso zonavimas. Preliminarūs užstatymo reglamentai“"(Vilniaus... 2006) labai kategoriškai, bet kartu ir liberaliai diferencijuoja dviejų terasų aukštingumo galimybes: viena - iki $35 \mathrm{~m}$, kita - iki $100 \mathrm{~m}$ (2 kreivè). Šiuo atveju maksimalios užstatymo galimybès tampa nebesuderinamos su geometrine „architektūrinès kalvos“ samprata ir vakarinèje dalyje pradeda užstoti Šeškinès kalvas.

Užstatymo aukštingumo metodika pagal tinklinę taškinę sistemą - skraistès modelị (Tinklinè... 2007) formalizuoja daugiau meninę poziciją - visų tuščių erdvių (dabartinių „dykrų“) architektūrinio užpildo koncepciją, kuriai kol kas šiek tiek trūksta urbanistinių struktūrinių kategorijų (3 kreivè). Atsižvelgus ị realius veiksnius (teritorijos morfologiją, esamą užstatymą, suprojektuotus pastatus), šis modelis ateityje galètų būti sẻkmingai taikomas.

Pagal maksimalius investicinius pageidavimus, patikrintus St „Vilniaus planas“ GIS duomenų bazèje, nubrèžta maksimalaus aukštingumo kreivè demonstruoja, kad einant šiuo keliu, užstatymas tampa nebevaldomas, agresyvus (4 kreivè). Tai griežtas priminimas, kad būtina pagaliau suvokti situacijos svarbą ir susitarti dèl stabilios ir nebedeformuotinos naujojo centro galutinès urbanistinès išraiškos. 

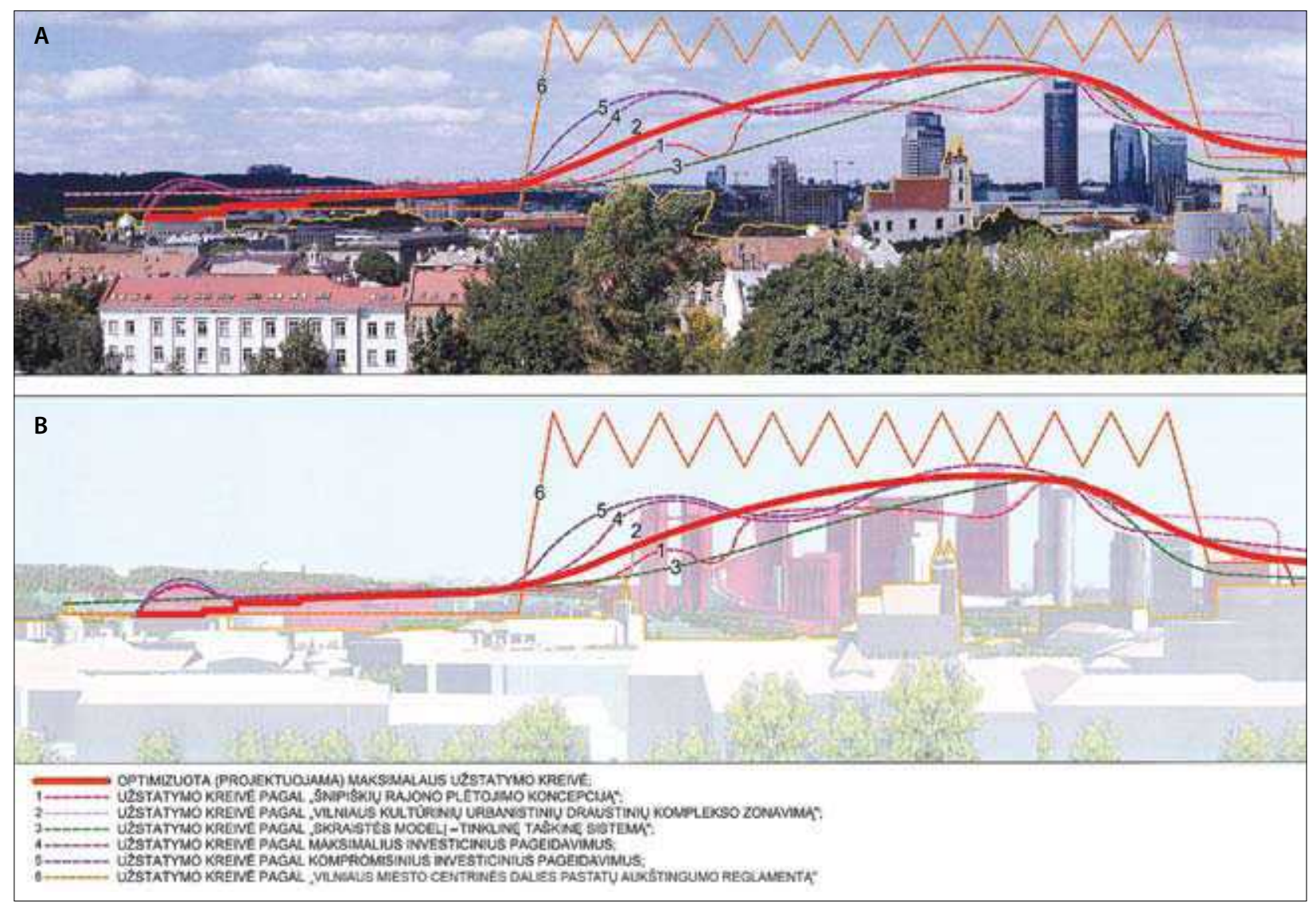

10 pav. Užstatymo aukštingumo alternatyvos: $A$ - esamos būklès kontekste; $B$ - planuojamoje situacijoje

Fig. 10. Alternatives for construction height: $A$ - existing situation; $B$ - planned situation

Yra aktyvūs kompromisiniai investiciniai pasiūlymai neaukštinti „kalvos“ aukščiau „Hanerio“ altitudès, o visa kita liberalizuoti (5 kreivè). Toks sprendimas jau vien formos požiūriu ne tik negelbejja padèties, bet dar ir ją pablogina. Atsiranda du beveik lygiaverčiai struktūros elementai - dvi kalvos. Tokiu atveju logiškas veiksmas būtų keisti visus „,architektūrinès kalvos“ parametrus, o visa kompozicinè prasmè turètų būti grindžiama kažkokiais kitokiais, o ne urbanistiniais struktūriniais kriterijais.

Pagal anksčiau rengtą aukštybinių pastatų išdèstymo specialųji planą (Vilniaus... 2004) ,architektūrinès kalvos" aukštingumas ruože tarp Konstitucijos prospekto ir Lvovo gatvès galëjo būti neribojamas (6 kreivè). Ši pozicija kèlè ir kelia pagrịstų abejonių, nes toks perspektyvinio užstatymo traktavimas būtų nebesuderinamas su globaliais miesto identiteto principais. Negrịžtamai deformuotųsi esminis urbanizuotos ir gamtinès aplinkos santykis. $\mathrm{O}$ tai lemtų ir kitos grandies morfostruktūros elementų parametrų didẻjimą, savaime nebetilpsiančių esamoje vilnietiškoje urbanistinèje struktūroje.

\section{Užstatymo intensyvumas}

Pagal nustatytą planuojamos teritorijos morfologinę struktūrą kiekviena planuojamos teritorijos sudètinè dalis turi nustatytą individualaus architektūrinių tūrių konstravimo principą. Šie kvartalų urbanistinių galimybių rodikliai planuojamo intensyviausio ir aukščiausio užstatymo ruože yra susieti su Vilniaus miesto bendrojo plano nuostatomis, kad teritorijos užstatymo reglamentus galima viršyti esant aiškiai deklaruotam viešajam interesui, ypatingai urbanistinei situacijai ir išskirtiniam pagrindimui. Nagrinèjamu atveju, kai siekiama išvengti galimos nepilnavertès galutinès urbanistinès išraiškos, bendruoju atveju tiesmukiškai taikant BP nurodytą maksimalus užstatymo intensyvumą UI sklypuose (umax $\leq 3,0$ ), planuojamoje teritorijoje intensyvumą būtina didinti. Pagal patikrintą urbanistinị modelị ir atsižvelgiant $i \mathfrak{~ a p l i n k o j e ~ e s a n c ̌ i o ~}$ užstatymo reglamentus - „architektūrinès kalvos“ 
zonoje užstatymo intensyvumą pagal aukštingumo dinamiką būtina padidinti iki $46 \%$ (umax $\leq 4,4)$.

Rytinès kalvos papèdès (užstatymo šalia Kalvariju gatvès) architektūrinè išraiška labai svarbi viso komplekso įvaizdžiui. Šiuo metu čia yra realiai stovintys neseniai realizuoti pastatai, esami senesnès statybos renovuoti ir nerenovuoti pastatai, galiojantys detalieji planai, taip pat užstatymo pasiūlymai, patikrinti architektūrinio konkurso būdu („Ibrahim“ pastatas). Viskas buvo daroma remiantis konkrečiais investiciniais nepamatuotais norais, susijusiais su atskirais sklypais, todèl dabar šios zonos vizualinès pasekmès beviltiškai chaotiškos ir nepavaldžios profesionaliam vertinimui.

\section{Išvados}

1.Problemos atsiradimo priežastys yra nekokybiški, nors ir atitinkantys teritorijų planavimo įstatymą, vietovių (dažniausiai atskirų sklypų) detalieji planai. Nereguliuojamos plètros toleravimas jau padarè ir toliau darytų didžiausią neigiamą poveikị miesto identitetui, kraštovaizdžiui, kultūros paveldui, materialiam turtui ir šių veiksnių tarpusavio sąveikai.

2.Bendruoju miestiniu požiūriu planuojama teritorija yra vieno iš svarbiausių miesto probleminių arealų aplinkoje, kol kas turinti nesuformuotą ir neintegralią urbanistinę struktūrą esamo ir kuriamo miesto centro teritorijų atžvilgiu. „Architektūrinès kalvos“ literatūrinès idèjos dešiniajame Neries krante urbanistinè samprata dar nebuvo apibrèžta urbanistinèmis kategorijomis. Todèl urbanistinè analizè ir jos išvadiniai teiginiai (sprendiniai) ir tolesnis požiūrio plètojimas gali turèti lemiamų teigiamų pasekmių Vilniaus urbanistinès morfologijos tęstinumui ir identitetui bei sostinès įvaizdžio formavimui.

3. Išaiškejja, kad siekiant pagerinti aplinkos kokybę, reikalingos sisteminès, koncentruotos pastangos organizuoti funkciškai ir socialiai integruotą miesto bei planuojamos teritorijos struktūrą ir formuoti vientisus kompaktiškus teritorijų struktūrinius vienetus.

4. Turint aiškius naujojo centro plètros ir formavimo principus, tikètini šie teigiami pokyčiai:

- sustiprès naujai kuriamos miesto centro dalies strateginè reikšmé;

- pagerès ir baigs formuotis vientisas urbanistinis architektūrinis centro įvaizdis, aplinkos kokybè igis aukštesnę kokybinę vertę;

- planuojama teritorija taps polifunkciškesnè ir labiau integruota visuomeninių interesų požiūriu;
- investicinè erdvè taps aiški, netransformuojama ir nepriklausoma nuo „teisètų lūkesčių“;

- pagal ịvertintą prognozuojamą investicinį talpumą bus tiksliai nustatytos investicinès galimybès, sureguliuotas konversijos mechanizmas ir pagaliau pabaigtos diskusijos dèl nepagrịsto investicijų stabdymo;

- neišvengiamai išryškès prielaidos miestovaizdžio pusiausvyrai palaikyti arba jai atkurti;

- bus nustatytos ir reglamentuotos sąlygos saugoti, ryškinti ir racionaliai naudoti kultūrinị ir gamtinị savitumą;

- atsiras objektyvios galimybės planuojamos teritorijos plètrai valdyti (plètra turi būti vykdoma ne stichiškai, o pagal poreikị ir galimybes pasirinktuose plètros segmentuose, numatant jos etapiškumą) ir konceptualiai svarbiausiems funkcinio zonavimo reglamentams nustatyti.

\section{Literatūra}

Daujotaite, I. M.; Laukaitytè-Malžinskienè, G. I. 2003. Vilniaus miesto centro urbanistinei kompozicijai turintys ịtakos Neries slènio gamtinès morfostruktūros ypatumai, Urbanistika ir architektūra XXVII (4): 156-159.

Daunora, Z. 2003. Vilniaus miesto centrinès dalies vizualinio identiteto apsaugos prioritetai, Urbanistika ir architektūra XXVII (1): 22.

Daunora, Z.; Kirvaitienė, S.; Vyšniūnas, A. 2004. Vilniaus miesto vizualinio identiteto apsauga ir pletros principai. Vilnius: Technika.

Daunora, Z. 2005. Kultūriniai ir struktūriniai miestų plètros uždaviniai valstybès normatyviniuose dokumentuose, Urbanistika ir architektūra XXIX (4): 164-173.

Drėma, V. 1991. Dingęs Vilnius. Vilnius: Vaga.

Mikučianis, V. 2001. Noréjau dirbti Lietuvoje. Vilnius: Vilniaus dailès akademijos leidykla. 101 p.

Racevičienè, A.; Baliulytè, I. 2008. Teritorijos tarp Kalvariju, Ukmergès, Geležinio Vilko gatviu, Neries upés istorines raidos analizés ir vertinimo duomenu bazé. SI „Vilniaus planas" archyvas.

Rodgers, R.; Power, A. 2004. Mažos valstybès miestai. Vilnius: Vilniaus dailès akademijos leidykla.

Šnipiškiu rajono plètojimas. Teritorijos tarp Geležinio Vilko, Žalgirio, Kalvariju gatviu ir Neries upés raidos programa. Moderni miesto centro dalis dešiniajame Neries krante. 2005. St „Vilniaus planas“. St „Vilniaus planas“ archyvas.

Tinkliné-taškiné sistema. 2007. UAB „Senojo miesto architektai", SI „Vilniaus planas" archyvas.

Vilniaus kultūriniu urbanistinių draustinių komplekso zonavimas. Preliminarūs užstatymo reglamentai. 2006. St „Vilniaus planas“, St „Vilniaus planas“ archyvas. 
Vilniaus miesto centrinès dalies pastatu aukštingumo reglamentas. 2004. St „Vilniaus planas“, VGTU Urbanistikos katedra, SI „Vilniaus planas" archyvas.

Vilniaus miesto savivaldybes teritorijos bendrasis planas $i k i$ 2015 metų. 2007. SI „Vilniaus planas“, SI „Vilniaus planas“ archyvas.

Vyšniūnas, A. 2003. Aukštybinių pastatų išdėstymo reglamentavimo Vilniaus miesto centriniame rajone metodiniai principai, Urbanistika ir architektūra XXVII (4): $37-139$.

Лебедев, Ю. С. 1975. Архитектура и техника. Москва: Знание. 37 с.

Линч, К. 1984. Образ города. Москва: Стройиздат.

\section{URBAN MODEL OF DEVELOPING VILNIUS MODERN CENTRE}

\section{Saulius Motieka}

Abstract. Urban development principles of the "urban hill" on the right bank of the Neris river, which now is developing rather chaotically, have major importance for further formation of Vilnius urban identity and for formation of qualitative image of the capital. Toleration of further unregulated development would have a huge negative influence on urban identity, landscape, cultural heritage, real estate, and on interaction of these subjects. Therefore, it is necessary to define clear development principles of the modern centre in order to describe its complete urbanistic image and secure multifunctionality for public needs. This will make the area clear for investment, create conditions for preservation, accentuation and rational use of cultural and natural heritage. It will create objective possibilities for development management and establishment of regulation principles for the analysed area.

Keywords: built-up area typology, urban structure, public space, urban landscape layers, "urban hill".

\section{SAULIUS MOTIEKA}

Architect, project manager, Municipal Enterprise "Vilniaus planas", Konstitucijos pr. 3, LT-09601 Vilnius, Lithuania. E-mail:saulius.motieka@vplanas.lt

Assoc Prof, Dept of Urban Design, Vilnius Gediminas Technical University (VGTU), Pylimo g. 26/Traku g. 1, LT-01332 Vilnius, Lithuania.

Projects: author and project manager of many master plans, detailed plans and building designs. Research interests: urbanism, land use planning. 